CESIS Electronic Working Paper Series

Paper No. 410

Ownership structure and firm export performance.

Evidence from Slovenian microdata

Črt Kostevc

June, 2015 


\title{
Ownership structure and firm export performance. Evidence from Slovenian microdata
}

\author{
Črt Kostevc ${ }^{\dagger}$ \\ Early draft. Comments and suggestions are very welcome. \\ Please do not cite or distribute
}

\begin{abstract}
This paper combines two very distinct strands of literature, firm-level trade analysis and studies on the impact of ownership structure. I explore the effects firm ownership structure has on its engagement with external trade using data for the population of Slovene enterprises between 2005 and 2013. The estimates indicate that concentrated firm ownership is more conducive to firms being exporters or becoming first-time exporters. Even after controlling for firm type, age, ownership type and ownership stability, firms with a larger ownership share held by the top five owners are more likely to become first-time exporters. While the association between the concentration of ownership and exporting status is slightly more ambiguous, overall the evidence favors concentrated ownership. Interestingly, the otherwise robust finding that foreign ownership improves the probability of exporting is restricted to limited-liability companies, while joint-stock companies show no association between lagged foreign ownership and export participation.
\end{abstract}

Keywords: Ownership structure, ownership stability, ownership type, exporting JEL classification: F14, G32

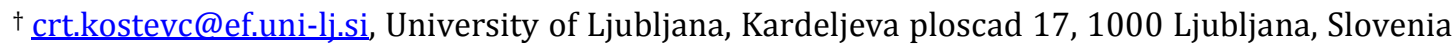
and Universitat de Valencia (visiting). I would like to thank Maria E. Rochina-Barrachina, Juan A. Máñez, the seminar participants at University of Valencia (March 2015) and University of Alicante (April 2015) for their helpful comments and suggestion. All errors and omissions herein are my own. 


\section{Introduction}

The effect of ownership structure and ownership dynamics on firm performance has long since been a feature of debate in the corporate finance literature. A long held belief that there exists an inverse relationship between firm performance and diffusion of ownership (Berle and Means, 1932) has since been challenged by Demsetz (1983). He argues that a corporation's ownership structure should be considered endogenous to firm performance and current-shareholder decisions. When owners of a limited liability or stock company choose to sell shares or agree to a secondary distribution of shares, they are in fact deciding to change the ownership structure and are likely to diffuse ownership. Ownership structure at any moment in time is a reflection of the decisions made by current and perspective future owners. According to Demsetz and Villalonga (2001) the ownership structure that emerges is impacted by the profit-maximizing interests of shareholders ensuring that there is no systematic relationship between variation ownership structure and variation in firm performance.

Several aspects of corporate ownership structure have been explored in connection with firm performance. While the longest tradition exists in empirical studies on the effects of ownership concentration on firm performance, other issues of interest include the effects of ownership dynamics and type of ownership on corporate performance. Long-term stability of ownership was found to have a positive effect on firm performance (see Hsu and Wang, 2014 for instance), but the impact of insider ownership is more ambiguous (Morck et al. 1988, Stulz 1988). Managers typically respond to two opposing forces. On one hand managerial ownership reduces agency costs and improves the motivation of managers, on the other, managerial entrenchment may lead to a reduction of firm value. With most of the empirical literature on the effects of institutional ownership focusing on the impact of insider ownership, no consensus has yet been reached on the direction and magnitude of these effects.

Another issue that has received extended empirical attention has also been that of foreign ownership, which has been a focus of extensive research in the international trade literature. Generally, foreign-owned firms are found to perform more efficiently than their domestically owned peers due to use of 
newer technology, stronger negotiating position vis-a-vis buyers and suppliers, more efficient international supply and distribution channels, etc. Several studies also explore the effect of foreign ownership on exporting-productivity nexus. That is, they analyze the effect foreign ownership has on the likelihood that firms of certain productivity start exporting or, alternatively, the importance of foreign ownership on the magnitude of productivity improvements stemming from exporting. To the best of my knowledge, no study yet explores the effects of other dimensions of ownership structure on firm exporting behavior. The aim of this paper is to bridge this gap in the literature.

The contribution of this paper to the literature is therefore the following. This is the first paper to explore the effect of ownership structure on the decision of a firm to become an exporter. The paper explores a broad set of potentially pertinent characteristics of ownership structure, such as type of owner and ownership stability on both the decision to trade internationally as well as extensive margin of cross-border trade. Results show that firms with a more concentrated ownership structure are likelier to be exporters and are also more likely to become first-time exporters. The effect of ownership concentration on export participation is revealed to be very robust and persistent.

The remainder of the paper is structured as follows. After a brief literature review, data and basic sample characteristics are presented in section 3 . Methodology and econometric issues are discussed in the fourth section, which is followed by the presentation of the results. Section 5 offers some conclusions.

\section{Literature review}

There is a long tradition of theoretical and empirical research on the interaction between a firm's principal and it's agent and, ultimately, the impact of this relationship on firm's performance (Berle and Means, 1932; Jensen and Meckling, 1976; Shleifer and Vishny, 1986). Agency theory contends that the interests of the absentee owners and their agents are misaligned which will ultimately lead to a deviation of managerial behavior away from the goal of maximization of firm value. Different measures of ownership structure have been repeatedly shown to play an important role in the principal-agent 
relationship, which in turn reflects the way a firm performs (see for example, Morck et al., 1988; McConnell and Servaes, 1990; Himmelberg et al., 1999).

The most often explored effect of ownership structure on firm performance is the concentration of ownership. While a belief that ownership concentration improves monitoring and mitigates agency problems (Claessens and Djankov, 1999; Prowse, 1992; Shleifer and Vishny, 1996) remains prevailing, it has been challenged by those who find that there should be no correlation between the two or even that ownership concentration negatively effects firm performance (see for instance Demsetz, 1983; Demsetz and Lehn, 1985; Barclay and Holderness, 1989 and Demsetz and Villalonga, 2001). Crucially from the perspective of this study, ownership concentration was found to be conducive to firms' innovation performance (e.g., Chang et al., 2006; Shleifer and Vishny, 1996; Chang and Hong, 2000; Rowley and Bae, 2004; Mahmood and Mitchell, 2004). These studies suggest that large-block shareholders are likely to prefer making long-term investments in R\&D in order to increase the stability of the firm, rather than seek short-term profit maximization.

The other area of intense empirical interest has been the identity or type of owners and their impact on firm performance. Specifically, insider ownership of managers, employees and affiliates is generally found to have a positive effect on firm performance due to a reduction in costs associated with the agency problem (McConnell and Servaes, 1990, Nickel, 1990; Kruse, 1993), although some studies have found that, due to manager entrenchment, the relationship between insider ownership and profitability may even be inverse (McConnell and Servaes, 1990; Morck et al., 1988). Furthermore, institutional owners have been shown to not only have a positive effect on financial performance, but also positively effect R\&D and diversification strategies (David et al., 2001; Tihanyi et al., 2003). In contrast to individual shareholders, institutional shareholders have a greater incentive to pressure managers and reduce potential agency costs. Moreover, Opler and Sokobin (1997) and Bushee (1998) show the positive impact of an institutional investor's role on the R\&D investment behavior of firms. Foreign institutional owners have also been shown to positively effect firm performance (Johanson and Vahlne, 1977; Kogut, 1983). Foreign partners have been reported to provide local firms with technical and managerial knowledge and resources. 
Finally, state ownership has been shown to exact a primarily negative effect on firm performance (Boycko et al., 1996; Dewenter and Malatesta, 2001) due to the nature of government choices with regard to social and political policy goals which tend to diverge from profit maximization. Overwhelmingly, the literature suggests that inefficient structure and oversight as well as lack of managerial knowledge make government ownership inefficient.

The final aspect of ownership structure that received relatively scant attention in the empirical literature is stability of ownership and its impact on firm performance. Theory suggests that more stable ownership would be conducive to longer term planning and strategic decisions, compared to a more volatile ownership structure, which might inject uncertainty into firms' operations. In spite of the fact that most studies focus on concentration of ownership, there is well-established evidence associating ownership stability with the outcomes of anti-takeover amendments, $R \& D$ investments, and acquisition decisions (Agrawal and Mandelker, 1990; Bushee, 1998; Gaspar et al., 2005). Chen et al. (2007) show that the benefit of monitoring increases with the size of ownership and duration of investment. Elyiasiani et al. (2010) provide evidence that stable ownership also leads to lower cost of debt.

While there are ample empirical studies exploring the effect of ownership on firm strategic choices (George et al., 2005, Zahra, 1996 and Zahra and Pearce, 1989), studies of the effect of ownership on exporting status and export performance are mostly limited to the impact foreign ownership has on firm exports. There are some notable exceptions mainly from the international business literature dealing with the effects of family ownership (Calabro et al. 2013), internal ownership (Miller, Le Breton-Miller, \& Scholnick, 2008), and organizational culture (Tesar \& Moini, 1998) on the speed of firm internationalization.

\section{Data and sample characteristics}

Data used in the analysis comes from three distinct databases. Accounting data for the population of Slovenian firms between 2005 and 2013 comes from AJPES (Agency of the Republic of Slovenia for Public Legal Records and Related 
Services). ${ }^{2}$ In addition to standard accounting data, we also have information on firm exports at the firm-aggregate level. Information on firm ownership comes from two sources: for limited liability companies (LLCs) the source is the Slovenian business register, also provided by AJPES, while the Central securities clearing corporation (KDD) provides ownership information on the top one hundred largest owners for public stock companies. While the ownership data have been anonymized, we have information on ownership share, type of owner and the date of change in ownership. There is more detailed information for public stock companies, for which we can also identify individual owners across time, allowing us to determine the stability of ownership. Firms are matched across the respective datasets using firm identifiers. The database covers between 50 and 55\% of the total population of firms in any given year. ${ }^{3}$ In 2012 firms in the sample account for $90.4 \%$ of total sales and $81.9 \%$ of total export volume. Some descriptive statistics for the data set are provided in Table 1 below.

Table 1: Descriptive statistics on key sample features (for years 2005 and 2012)

\begin{tabular}{|c|c|c|c|c|c|}
\hline & & \multicolumn{2}{|c|}{ legal form } & \multicolumn{2}{|c|}{ export status } \\
\hline \multicolumn{2}{|l|}{ year } & JSC & PLC/LLC & non-exporter & exporter \\
\hline \multirow[t]{4}{*}{2005} & \# of firms & 689 & 37,579 & 28,321 & 9,831 \\
\hline & Mean share of top owner & 0.55 & 0.80 & 0.81 & 0.76 \\
\hline & Mean share of top 5 owners & 0.81 & 1.00 & 1.00 & 0.99 \\
\hline & Mean \# of owners & 1325.3 & 2.1 & 20.5 & 41.8 \\
\hline \multirow[t]{4}{*}{2012} & \# of firms & 548 & 56,719 & 41,137 & 16,130 \\
\hline & Mean share of top owner & 0.60 & 0.81 & 0.83 & 0.78 \\
\hline & Mean share of top 5 owners & 0.85 & 0.97 & 0.98 & 0.96 \\
\hline & Mean \# of owners & 977.4 & 1.7 & 8.18 & 18 \\
\hline
\end{tabular}

Source: AJPES, KDD

Note: "Mean share of top owner" and "Mean share of top five owners" given in ratios of the total ownership.

\footnotetext{
2 While the AJPES database comprises the complete financial accounting records for all types of firms, less stringent reporting standards for single proprietors and cooperatives mean that the dataset is effectively restricted to limited liability and joint-stock companies.

3 The remaining firms are primarily sole proprietors and cooperatives.
} 
Table 2: Descriptive statistics on key sample features (for 2012)

\begin{tabular}{ll|rr}
\hline & & \multicolumn{2}{|c}{ legal form } \\
\hline Exporter status & \multicolumn{1}{|c|}{ JSC } & PLC/LLC \\
\hline \multirow{3}{*}{ Non-exporters } & \# of firms & 235 & 40,902 \\
& Mean share of top owner & 0.60 & 0.83 \\
& Mean share of top 5 owners & 0.84 & 0.98 \\
& Mean \# of owners & 1153.0 & 1.6 \\
& & & 15,817 \\
Exporters & \# of firms & 313 & 0.78 \\
& Mean share of top owner & 0.60 & 0.96 \\
& Mean share of top 5 owners & 0.85 & 1.8 \\
\hline
\end{tabular}

Source: AJPES, KDD

Note: "Mean share of top owner" and "Mean share of top five owners" given in ratios of the total ownership.

The majority of firms in the sample are revealed to be non-exporting limited liability companies, which represent 71 percent of the sample in 2012 Ownership is substantially more dispersed for joint-stock companies compared to LLCs. The ownership of the later is heavily concentrated in the hands of the largest owner, who on average controls $84 \%$ of the firm share for non-exporting and $78 \%$ for exporting firms. The average ownership concentration measures suggest that non-exporting limited liability firms have the most concentrated ownership, followed by exporting LLCs. Predictably, ownership concentration is far smaller for JSCs, where the difference between exporters and non-exporters is negligible.

\section{Methodology}

While there is ample evidence for the effect of ownership structure on firm performance, its impact on exporting is decidedly underexplored. Whether to export or not is clearly one of the more important strategic decisions a firm will make. It is comparable to such choices as how to finance firm operations, whether to invest in R\&D, what marketing strategy to adopt etc. For this reason, I follow the identification approach common to the strategic ownership literature and apply it to the firms export choice. 
The basic premise of the empirical strategy is therefore that the structure of ownership, its dynamics and type of owners has an effect on firm performance. The focus of my analysis will be on the choice of whether or not to export as well as the intensity of exports. Ownership's impact is going to be estimated by regressing exporting status and the share of exporting in total sales ${ }^{4}$ on variables measuring the structure of ownership. The basic empirical model is described by equation 1. Firm subscripts are dropped for brevity.

$$
P\left(\exp _{t}=1\right)=+{ }_{1} \text { top5_share }{ }_{t 1}+{ }_{2} \mathrm{HHI}_{t 1}+{ }_{3} \text { no_own } t_{1}+{ }_{4} \text { controls }{ }_{1}+{ }_{t}
$$

where $\exp _{t}$ is the export status indicator variable at time t. top5_sharet-1 measures the ownership share of the top five largest owners. In order to capture concentration of ownership beyond the largest five owners, I also include the lagged Hirschman-Herfindahl index $\left(H H I_{t-1}\right)$, which measures ownership concentration on data for all owners (or largest 100 owners in the case of jointstock companies). As a final measure of ownership structure the lagged natural logarithm of the number of owners is included in the regression (no_own $\left.n_{t-1}\right)$. Both firm ownership structure and its engagement in exporting are likely features of firm evolution from a startup to an established firm. For this reason it is important to also control for firm age in the regressions in order not to get a spurious correlation between ownership and firm activity. Furthermore, additional ownership control variables are included, such as type of dominant owner (private domestic institutional owners, foreign owners, individual or physical domestic owners, directly state owned and indirectly state owned) and stability of ownership 5 (ownership persistence and institutional volatility). Type of ownership in one of the key features discussed in the corporate finance literature with respect to the effects of ownership on firm performance. As discussed in the literature survey segment, foreign-owned firms and firms owned by domestic institutional investors are likely to perform better than those

\footnotetext{
${ }^{4}$ First-time exporter dummy was also used as the dependent variable to gain better insight into the causality between ownership structure and exporting status.

${ }^{5}$ We can only calculate ownership stability indicators for joint-stock companies, as data on individual owner identities is not available for LLCs. This noticeably restricts the sample size of regressions that include information on the stability of ownership.
} 
owned primarily by outside individual shareholders or the state. ${ }^{6}$ Data on whether owners are firm insiders (family ownership, manager ownership or ownership of associated agents) has not been made available to me. This limitation of the dataset impacts the interpretation of results. As it stands, internal owners are lumped together with other individual private owners, which will potentially overstate the effect of individual ownership compared to other studies.

In constructing the measures of ownership stability I follow Elyasiani et al. (2010) and define two measures of ownership continuity. Institutional volatility is defined as:

$$
\text { Inst_volat } t_{t}{ }_{j=1}^{J} s d\left(p_{t}^{j}\right) / J
$$

where $p_{t}^{j}$ is the share of owner $j$ of firm $i$ in time $t, s d\left(p_{t}^{j}\right)$ is the standard deviation of owner $j$ 's share at time $t$ and $J$ is the number of owners. Larger values of Inst_volat $t_{t}$ indicate more volatile ownership shares. Institutional ownership persistence by:

$$
\text { own_persist }={ }_{j=1}^{J} p_{t=1}^{4} / 4 \div / \operatorname{sd}\left(p_{t}^{j}\right) / J
$$

The standard deviations of the ownership share are calculated on a four-year moving basis, which, while demanding on the sample size, presents an acceptable compromise between measurement of the standard deviation and sample size. ${ }^{7}$ Higher values of the ownership persistence indicator imply more stable ownership.

\footnotetext{
${ }^{6}$ In order to control for ownership type, indicator variables that assume value 1 , if a particular ownership type assumes at least $25 \%$ of the ownership and 0 otherwise, are included in the regression. I have also tried using other cut-offs $(10 \%$ and $50 \%$, respectively), but that did not lead to qualitatively different estimates.

${ }^{7}$ Elyasiani et al. (2010) use quarterly data and are able to calculate standard deviation based on 12 successive quarters. Unfortunately, I do not have balance sheet information on the quarter-by-quarter basis and cannot follow suit.
} 
Table 2: Correlation matrix for key variables of interest

\begin{tabular}{|c|c|c|c|c|c|c|c|}
\hline & $\begin{array}{l}\text { Export } \\
\text { status }\end{array}$ & $\begin{array}{l}\text { Share of } \\
\text { largest }\end{array}$ & $\begin{array}{l}\text { Share of } 5 \\
\text { largest }\end{array}$ & $\mathrm{HHI}$ & $\begin{array}{l}\text { Owner. } \\
\text { persist. }\end{array}$ & $\begin{array}{l}\text { Institutional } \\
\text { volatility }\end{array}$ & $\begin{array}{l}\log \# \text { of } \\
\text { owners }\end{array}$ \\
\hline Export status & 1 & & & & & & \\
\hline $\begin{array}{c}\text { Share of largest } \\
\text { owner }\end{array}$ & $\begin{array}{l}-0.110 \\
(0.000)\end{array}$ & 1 & & & & & \\
\hline $\begin{array}{l}\text { Share of the } \\
\text { five largest }\end{array}$ & $\begin{array}{l}-0.060 \\
(0.000)\end{array}$ & $\begin{array}{c}0.353 \\
(0.000)\end{array}$ & 1 & & & & \\
\hline HHI & $\begin{array}{l}-0.127 \\
(0.000)\end{array}$ & $\begin{array}{c}0.986 \\
(0.000)\end{array}$ & $\begin{array}{c}0.386 \\
(0.000)\end{array}$ & 1 & & & \\
\hline $\begin{array}{l}\text { Ownership } \\
\text { persistence }\end{array}$ & $\begin{array}{l}-0.028 \\
(0.032)\end{array}$ & $\begin{array}{l}-0.001 \\
(0.952)\end{array}$ & $\begin{array}{c}0.016 \\
(0.207)\end{array}$ & $\begin{array}{c}0.001 \\
(0.954)\end{array}$ & 1 & & \\
\hline $\begin{array}{c}\text { Institutional } \\
\text { volatility }\end{array}$ & $\begin{array}{l}-0.004 \\
(0.729)\end{array}$ & $\begin{array}{c}0.094 \\
(0.000)\end{array}$ & $\begin{array}{c}0.098 \\
(0.000)\end{array}$ & $\begin{array}{c}0.120 \\
(0.000)\end{array}$ & $\begin{array}{l}-0.003 \\
(0.813)\end{array}$ & 1 & \\
\hline $\begin{array}{l}\text { Log number of } \\
\text { owners }\end{array}$ & $\begin{array}{c}0.150 \\
(0.000)\end{array}$ & $\begin{array}{l}-0.680 \\
(0.000)\end{array}$ & $\begin{array}{l}-0.210 \\
(0.000)\end{array}$ & $\begin{array}{l}-0.721 \\
(0.000)\end{array}$ & $\begin{array}{l}-0.026 \\
(0.051)\end{array}$ & $\begin{array}{l}-0.169 \\
(0.000)\end{array}$ & 1 \\
\hline
\end{tabular}

Source: AJPES, KDD, own calculations

Note: Statistical significance given in parenthesis below the correlation coefficient.

Finally, I also include variables that serve as standard control variables for exporting status in firm-level trade literature. Lagged values of (logarithms) labor productivity, employment and capital intensity are included in the regression in addition to time and 4-digit industry dummies. Lastly, dummies for the two firm types (joint-stock and limited-liability companies) are introduced as additional controls.

Associations between key variables of interest are explored further with a correlation matrix (Table 2), which reveals strong linkages among the structure of ownership and export status.

Apart from institutional volatility, the remaining variables appear highly correlated with export status. All measures of ownership concentration, share of largest owner, largest five owners and $\mathrm{HH}$ index are all negatively correlated with export status, while the number of owners is positively correlated. Ownership persistence is negatively correlated with export status.

\section{Econometric issues}

The benchmark estimates of equation 1 performed using probit estimators and probit estimators with controls for unobserved heterogeneity (Blundell et al. 1999, 2002). While the incidental variable problem prevents the use of standard firm-fixed effects in probit models, the solution proposed by Blundell et al. is to employ presample average values of the dependent variable to control for the 
unobserved fixed effects. I follow Mañez et al. (2014) in applying the methodology to the export propensity specification. I use the first two years of the sample to create the out-of-sample averages, therefore the nine-year sample period is reduced to seven years for this regression. In addition to the dependent variable, as suggested by Blundell et al. (1999), pre-sample average values of the time-varying regressors are also included as further controls for firm-level heterogeneity. 8

While all regressors are lagged to avoid simultaneity, those are likely to remain a problem, in particular if the variables in question are serially correlated. Demsetz and Villalonga (2001) argue that the ownership structure should be treated as endogenous to firm performance. Although they focus on accounting profit as a measure of firm performance, the same argument could easily be extended to other features of successful firms, such as exporting, innovation success, outward foreign direct investment etc. The idea that ownership structure is the choice of current and future owners, which is in part based on expectations of future firm performance, implies that ownership structure is endogenous. For the purpose of dealing with the possible endogeneity of both ownership structure variables as well as labor productivity in the export status equation, I instrumentalize these variables using system GMM estimation. The ensuing section presents the estimation results.

\section{Results}

Benchmark estimates of (1) are presented in Table 3. The dependent variable used in these estimates is the exporter dummy. In these estimates each ownership structure indicator's impact is evaluated individually (log number of owners, share of largest owner, sum of the share of largest five owners and ownership concentration index). ${ }^{9}$

\footnotetext{
${ }^{8}$ Given that the main variables of interest: number of owners, share of the five largest owners and index of ownership concentration do not have much "within" variation (the shares of variation in these variables due to time are, respectively, $4.3 \%, 26.8 \%$, and $15.8 \%$ ). Hence, only pre-sample averages of labor value added, employment and capital intensity are used as additional regressors.

${ }_{9}$ The sample is restricted to firms with, on average, more than one owner. The complete sample equivalent of Table 3 is provided in the Appendix.
} 
Table 3: Estimates of (1) with OLS [Dependent variable: Export status dummy]

(1) (2) (3) (4)

\begin{tabular}{|c|c|c|c|c|}
\hline VARIABLES & $\mathrm{P}\left(\operatorname{Exp}_{\mathrm{t}}=1\right)$ & $\mathrm{P}\left(\operatorname{Exp}_{\mathrm{t}}=1\right)$ & $\mathrm{P}\left(\operatorname{Exp}_{\mathrm{t}}=1\right)$ & $\mathrm{P}\left(\operatorname{Exp}_{\mathrm{t}}=1\right)$ \\
\hline $\mathrm{Ln}(\mathrm{VA} / \mathrm{emp})_{\mathrm{t}-1}$ & $\begin{array}{c}0.322 * * * \\
(0.007)\end{array}$ & $\begin{array}{c}0.323 * * * \\
(0.007)\end{array}$ & $\begin{array}{c}0.322 * * * \\
(0.007)\end{array}$ & $\begin{array}{l}0.322 * * * \\
(0.007)\end{array}$ \\
\hline $\operatorname{Ln}(\mathrm{emp})_{\mathrm{t}-1}$ & $\begin{array}{l}0.318 * * * \\
(0.005)\end{array}$ & $\begin{array}{l}0.316^{* * * *} \\
(0.005)\end{array}$ & $\begin{array}{c}0.317 * * * \\
(0.005)\end{array}$ & $\begin{array}{l}0.315^{* * *} \\
(0.005)\end{array}$ \\
\hline $\operatorname{Ln}(\mathrm{K} / \mathrm{emp})_{\mathrm{t}-1}$ & $\begin{array}{l}0.094 * * * \\
(0.006)\end{array}$ & $\begin{array}{l}0.093 * * * \\
(0.006)\end{array}$ & $\begin{array}{c}0.094 * * * \\
(0.006)\end{array}$ & $\begin{array}{l}0.093 * * * \\
(0.006)\end{array}$ \\
\hline $\operatorname{Ln}(\text { no. of owners })_{\mathrm{t}-1}$ & $\begin{array}{l}-0.019 * \\
(0.010)\end{array}$ & & & \\
\hline Share of largest owner $r_{t-1}$ & & $\begin{array}{c}0.007 \\
(0.026)\end{array}$ & & \\
\hline Share of top 5 owners $_{\mathrm{t}-1}$ & & & $\begin{array}{l}0.088 * \\
(0.049)\end{array}$ & \\
\hline HHI (ownership) $)_{\mathrm{t}-1}$ & & & & $\begin{array}{l}-0.002 \\
(0.026)\end{array}$ \\
\hline Foreign majority owner & $\begin{array}{l}0.473 * * * \\
(0.072)\end{array}$ & $\begin{array}{l}0.471 * * * \\
(0.073)\end{array}$ & $\begin{array}{c}0.478 * * * \\
(0.072)\end{array}$ & $\begin{array}{l}0.481 * * * \\
(0.072)\end{array}$ \\
\hline $\begin{array}{l}\text { Private institutional } \\
\text { ownership }\end{array}$ & $\begin{array}{c}-0.073 * * \\
(0.031)\end{array}$ & $\begin{array}{c}-0.075 * * \\
(0.032)\end{array}$ & $\begin{array}{c}-0.071 * * \\
(0.031)\end{array}$ & $\begin{array}{c}-0.072 * * \\
(0.032)\end{array}$ \\
\hline $\begin{array}{l}\text { Physical person owners } \\
\text { only }\end{array}$ & $\begin{array}{l}0.079 * * * \\
(0.021)\end{array}$ & $\begin{array}{l}0.085 * * * \\
(0.021)\end{array}$ & $\begin{array}{l}0.085 * * * \\
(0.021)\end{array}$ & $\begin{array}{l}0.086^{* * * *} \\
(0.021)\end{array}$ \\
\hline State direct ownership & $\begin{array}{l}-0.045 \\
(0.188)\end{array}$ & $\begin{array}{l}-0.022 \\
(0.173)\end{array}$ & $\begin{array}{l}-0.141 \\
(0.170)\end{array}$ & $\begin{array}{l}-0.136 \\
(0.170)\end{array}$ \\
\hline State indirect ownership & $\begin{array}{c}0.440 * * * \\
(0.169)\end{array}$ & $\begin{array}{l}0.337 * * \\
(0.170)\end{array}$ & $\begin{array}{c}0.426 * * \\
(0.168)\end{array}$ & $\begin{array}{l}0.422 * * \\
(0.169)\end{array}$ \\
\hline Age & $\begin{array}{c}-0.009 * * * \\
(0.001)\end{array}$ & $\begin{array}{c}-0.009 * * * \\
(0.001)\end{array}$ & $\begin{array}{c}-0.009 * * * \\
(0.001)\end{array}$ & $\begin{array}{c}-0.009 * * * \\
(0.001)\end{array}$ \\
\hline Constant & $\begin{array}{c}-4.812 * * * \\
(0.202)\end{array}$ & $\begin{array}{c}-4.829 * * * \\
(0.189)\end{array}$ & $\begin{array}{c}-4.874 * * * \\
(0.191)\end{array}$ & $\begin{array}{c}-4.798 * * * \\
(0.187)\end{array}$ \\
\hline Time dummies & YES & YES & YES & YES \\
\hline Legal status dummies & YES & YES & YES & YES \\
\hline Industry dummies & YES & YES & YES & YES \\
\hline Observations & 76,866 & 76,850 & 76,892 & 76,892 \\
\hline Pseudo $\mathrm{R}^{2}$ & 0.250 & 0.250 & 0.250 & 0.250 \\
\hline
\end{tabular}

Standard errors in parentheses. ${ }^{* * *} \mathrm{p}<0.01, * * \mathrm{p}<0.05, * \mathrm{p}<0.1$

Estimates in Table 3 show that labor productivity, firm size and capital intensity positively impact the likelihood of being an exporter. The ownership structure indicator variables offer weak indication that more concentrated ownership increases the probability of being an exporter.

From Table 3, it can be seen that the total number of shareholders/owners is negatively associated with exporting probability, while two of the ownership concentration measures (largest owner share and share of the largest 5 owners) are positively correlated with exporting status. Three of the four indicators point to a positive correlation between exporting status and ownership concentration, 
although only two significantly so. Foreign ownership and ownership by individuals also positively effects the probability of exporting, while state and domestic institutional owners have a predominantly negative effect.

Dependent variables used in Table 4 are export status and export start indicators. The effect of the ownership structure variables on export participation is henceforth estimated jointly. The reason for this is that no single indicator completely describes the structure of firm ownership, while several of them combined offer deeper insight.

Estimates of ownership structure variables show a nuanced picture. While both the number of owners (weakly) and ownership share of top five owners indicate that concentrated ownership improves the likelihood to export or become a firsttime exporter, the coefficient on the ownership concentration index (HHI) is significantly negative. The latter indicates that while ownership concentration at the top is beneficial to exporting, with the remaining owners' shares being more dispersed. Namely, controlling for the share of top five owners and the number of owners, a lower concentration index improves the likelihood of exporting, indicating that the shares of the remaining owners have to be more dispersed. ${ }^{10}$ Finally, while foreign and domestic private (individual) owners appear to have a positive effect on export status, domestic institutional owners have a negative impact on export status. 11

\footnotetext{
${ }^{10}$ An alternative explanation could be that holding the concentration index constant, the share of top 5 owners has to increase in order to improve the export propensity. By default, this would imply a dispersion in minority ownership shares.

${ }^{11}$ A more detailed breakdown of the effect of institutional ownership is presented in the Appendix (Table A2). Results reveal that the negative effect is generated by observations with non-financial owners (non-bank or insurance firm owners), the IO matrix share between owner and affiliate surprisingly has a positive effect on export status.
} 
Table 4: Estimates of (1) with OLS [Dependent variable: Export status dummy (1) and (2) and Export start dummy (3)]

\begin{tabular}{|c|c|c|c|}
\hline VARIABLES & $\begin{array}{c}(1) \\
\mathrm{P}\left(\operatorname{Exp}_{\mathrm{t}}=1\right)\end{array}$ & $\begin{array}{c}(2) \\
\mathrm{P}\left(\operatorname{Exp}_{\mathrm{t}}=1\right)\end{array}$ & $\begin{array}{c}(3) \\
\mathrm{P}\left(\operatorname{Exp}_{\mathrm{t}}=1 \mid \operatorname{Exp}_{\mathrm{t}-1}=0\right)\end{array}$ \\
\hline $\operatorname{Exp}_{t-1}$ & & $\begin{array}{c}2.084 * * * \\
(0.008)\end{array}$ & \\
\hline Single owner ${ }_{t-1}$ & $\begin{array}{l}-0.000 \\
(0.000)\end{array}$ & $\begin{array}{l}-0.000 \\
(0.000)\end{array}$ & $\begin{array}{l}-0.000 \\
(0.000)\end{array}$ \\
\hline $\operatorname{Ln}(\mathrm{VA} / \mathrm{emp})_{\mathrm{t}-1}$ & $\begin{array}{c}0.312 * * * \\
(0.004)\end{array}$ & $\begin{array}{l}0.161 * * * \\
(0.005)\end{array}$ & $\begin{array}{l}0.107 * * * \\
(0.006)\end{array}$ \\
\hline $\operatorname{Ln}(\mathrm{emp})_{\mathrm{t}-1}$ & $\begin{array}{c}0.319 * * * \\
(0.003)\end{array}$ & $\begin{array}{c}0.166^{* * *} \\
(0.003)\end{array}$ & $\begin{array}{c}0.102 * * * \\
(0.004)\end{array}$ \\
\hline $\operatorname{Ln}(\mathrm{K} / \mathrm{emp})_{\mathrm{t}-1}$ & $\begin{array}{c}0.060 * * * \\
(0.003)\end{array}$ & $\begin{array}{c}0.035 * * * \\
(0.004)\end{array}$ & $\begin{array}{c}0.058 * * * \\
(0.005)\end{array}$ \\
\hline $\operatorname{Ln}(\text { no. of owners })_{t-1}$ & $\begin{array}{l}-0.003 \\
(0.010)\end{array}$ & $\begin{array}{c}0.005 \\
(0.012)\end{array}$ & $\begin{array}{c}-0.042 * * \\
(0.017)\end{array}$ \\
\hline Share of top 5 owners t-1 & $\begin{array}{c}0.175^{* * * *} \\
(0.037)\end{array}$ & $\begin{array}{c}0.118 * * * \\
(0.046)\end{array}$ & $\begin{array}{c}0.225 * * * \\
(0.063)\end{array}$ \\
\hline HHI (ownership) $)_{t-1}$ & $\begin{array}{c}-0.157 * * * \\
(0.021)\end{array}$ & $\begin{array}{c}-0.088 * * * \\
(0.026)\end{array}$ & $\begin{array}{c}-0.176 * * * \\
(0.035)\end{array}$ \\
\hline Foreign majority owner & $\begin{array}{c}0.576^{* * * *} \\
(0.039)\end{array}$ & $\begin{array}{c}0.284 * * * \\
(0.046)\end{array}$ & $\begin{array}{c}0.286^{* * * *} \\
(0.069)\end{array}$ \\
\hline $\begin{array}{l}\text { Private institutional } \\
\text { ownership }\end{array}$ & $\begin{array}{c}-0.101 * * * \\
(0.023)\end{array}$ & $\begin{array}{l}-0.043 \\
(0.028)\end{array}$ & $\begin{array}{c}0.007 \\
(0.037)\end{array}$ \\
\hline $\begin{array}{l}\text { Physical person owners } \\
\text { only }\end{array}$ & $\begin{array}{c}0.065 * * * \\
(0.014)\end{array}$ & $\begin{array}{l}0.078 * * * \\
(0.017)\end{array}$ & $\begin{array}{l}0.138 * * * \\
(0.021)\end{array}$ \\
\hline State direct ownership & $\begin{array}{c}0.375 * * \\
(0.165)\end{array}$ & $\begin{array}{c}0.293 \\
(0.206)\end{array}$ & $\begin{array}{c}0.321 \\
(0.386)\end{array}$ \\
\hline State indirect ownership & $\begin{array}{c}0.483 * * * \\
(0.165)\end{array}$ & $\begin{array}{c}0.312 \\
(0.206)\end{array}$ & $\begin{array}{c}0.357 \\
(0.389)\end{array}$ \\
\hline Age & $\begin{array}{c}-0.009^{* * * *} \\
(0.001)\end{array}$ & $\begin{array}{c}-0.010^{* * *} \\
(0.001)\end{array}$ & $\begin{array}{c}-0.016^{* * *} \\
(0.001)\end{array}$ \\
\hline Constant & $\begin{array}{c}-4.581 * * * \\
(0.163)\end{array}$ & $\begin{array}{c}-3.621^{* * * *} \\
(0.194)\end{array}$ & $\begin{array}{c}-3.215^{* * * *} \\
(0.302)\end{array}$ \\
\hline Time dummies & YES & YES & YES \\
\hline Legal status dummies & YES & YES & YES \\
\hline Industry dummies & YES & YES & YES \\
\hline $\begin{array}{l}\text { Observations } \\
\text { Pseudo } \mathrm{R}^{2}\end{array}$ & $\begin{array}{c}218,037 \\
0.242\end{array}$ & $\begin{array}{c}218,037 \\
0.517\end{array}$ & $\begin{array}{c}154,412 \\
0.0558\end{array}$ \\
\hline
\end{tabular}

Standard errors in parentheses. $* * * p<0.01,{ }^{* *} \mathrm{p}<0.05,{ }^{*} \mathrm{p}<0.1$

In order explore the duration of the effect of ownership on exporting status, we also estimate (1) with longer lags on the ownership-structure variables. For the sake of convenience, in Table 5 the presentation of results is restricted solely to indicators of ownership for the sake of convenience. 
Table 5: Estimates of (1) with OLS [Dependent variable: Export status dummy]

\begin{tabular}{ccccc}
\hline & $\mathrm{n}=2$ & $\mathrm{n}=3$ & $\mathrm{n}=4$ & $\mathrm{n}=5$ \\
\hline Ln(no. of & -0.005 & -0.009 & -0.010 & -0.016 \\
owners) & $(0.011)$ & $(0.012)$ & $(0.014)$ & $(0.016)$ \\
Share of top 5 & $0.218 * * *$ & $0.265 * * *$ & $0.486 * * *$ & $0.527 * * *$ \\
owners $_{\mathrm{t}-\mathrm{n}}$ & $(0.045)$ & $(0.061)$ & $(0.102)$ & $(0.125)$ \\
HHI & $-0.147 * * *$ & $-0.153 * * *$ & $-0.150 * * *$ & $-0.169 * * *$ \\
(ownership) $_{\mathrm{t}-\mathrm{n}}$ & $(0.023)$ & $(0.025)$ & $(0.029)$ & $(0.035)$ \\
\hline
\end{tabular}

Standard errors in parentheses. $* * * p<0.01, * * p<0.05, * p<0.1$

Note: Although separate complete regressions of (1) were done, only coefficients of the ownership variables are presented for the sake of brevity.

The ownership concentration as measured by the share of top five owners is positively correlated with exporting status regardless of the length of lag. If anything, longer lags appear to increase the size of the effect. Similarly, the negative effect of effect of $\mathrm{HH}$ index of ownership concentration is also maintained with greater lags. As both the share of the largest owners and the HHI index are measured by indices (between 0 and 1), the size of the coefficients can be compared. The magnitude of the effect of the share of top five owners on the probability of exporting is almost four times that of the concentration of ownership. The number of owners, although displaying negative correlation, is not significantly correlated with export status regardless of the length of the lag. As is common for firm-level studies, the estimates may suffer from omitted variable bias as one cannot account for managerial abilities, firm-specific demand shocks, and even true total factor productivity. In order to mitigate the effect of omitted variables on the estimation, an augmented version of (1) is reestimated with random-effect probit as suggested by Blundell et al. (2002). These results are presented in Table 6.

The previous estimates are supported by the random-effects estimates as the findings are maintained both in terms of sign and magnitude of the main coefficients of interest. Foreign-owned firms and firms owned by individual investors are shown to be more likely to both be exporters and become first-time exporters. Concentration of ownership (HHI) has a negative effect on the probability of being an exporter, but no significant effect on the probability of becoming an exporter. While concentration of ownership is negatively correlated 
with the likelihood of being an exporter, it is positively associated with the probability of becoming a first-time exporter.

Table 6: Controlling for fixed effects in xtprobit estimation of (1)

(1)

$\mathrm{P}\left(\operatorname{Exp}_{\mathrm{t}}=1\right)$

\begin{tabular}{|c|c|}
\hline VARIABLES & $\mathrm{P}\left(\operatorname{Exp}_{\mathrm{t}}=1\right)$ \\
\hline \multicolumn{2}{|l|}{ Structural parameters } \\
\hline Export status $_{\mathrm{t}-1}$ & $\begin{array}{l}1.209 * * * \\
(0.015)\end{array}$ \\
\hline $\operatorname{Ln}(\mathrm{VA} / \mathrm{emp})_{\mathrm{t}-1}$ & $\begin{array}{c}0.180 * * * \\
(0.009)\end{array}$ \\
\hline $\operatorname{Ln}(\mathrm{emp})_{\mathrm{t}-1}$ & $\begin{array}{c}0.024 * * * \\
(0.009)\end{array}$ \\
\hline $\operatorname{Ln}(\mathrm{K} / \mathrm{emp})_{\mathrm{t}-1}$ & $\begin{array}{c}0.245^{* * *} \\
(0.010)\end{array}$ \\
\hline $\operatorname{Ln}(\text { no. of owners })_{t-1}$ & $\begin{array}{l}-0.002 \\
(0.020)\end{array}$ \\
\hline Share of top 5 owners $_{t-1}$ & $\begin{array}{c}0.127 * * \\
(0.063)\end{array}$ \\
\hline HHI (ownership) $)_{t-1}$ & $\begin{array}{c}-0.158 * * * \\
(0.043)\end{array}$ \\
\hline Foreign majority owner & $\begin{array}{c}0.205^{* * *} \\
(0.059)\end{array}$ \\
\hline Private inst. ownership & $\begin{array}{l}-0.038 \\
(0.036)\end{array}$ \\
\hline Physical person owners & $\begin{array}{c}0.062 * * * \\
(0.022)\end{array}$ \\
\hline State direct ownership & $\begin{array}{c}0.231 \\
(0.333)\end{array}$ \\
\hline State indirect ownership & $\begin{array}{c}0.379 \\
(0.328)\end{array}$ \\
\hline Age & $\begin{array}{c}-0.021 * * * \\
(0.001)\end{array}$ \\
\hline Constant & $\begin{array}{l}1.209 * * * \\
(0.015)\end{array}$ \\
\hline Nuisance parameters & \\
\hline Export status $_{\text {presample }}$ & $\begin{array}{c}1.443 * * * \\
(0.025)\end{array}$ \\
\hline $\mathrm{Ln}(\mathrm{VA} / \mathrm{emp})_{\text {presample }}$ & $\begin{array}{c}0.058 * * * \\
(0.011)\end{array}$ \\
\hline $\operatorname{Ln}(\mathrm{emp})_{\text {presample }}$ & $\begin{array}{l}-0.011 \\
(0.011)\end{array}$ \\
\hline $\operatorname{Ln}(\mathrm{K} / \mathrm{emp})_{\text {presample }}$ & $\begin{array}{c}0.057 * * * \\
(0.009)\end{array}$ \\
\hline Time dummies & YES \\
\hline Legal status dummies & YES \\
\hline Industry dummies & YES \\
\hline $\begin{array}{l}\text { Observations } \\
\text { Wald } \chi^{2}(106)\end{array}$ & $\begin{array}{c}190,228 \\
43791.99\end{array}$ \\
\hline
\end{tabular}

Standard errors in parentheses

$* * * \mathrm{p}<0.01,{ }^{* *} \mathrm{p}<0.05, * \mathrm{p}<0.1$ 
Effect of ownership concentration and structure on firm experience with foreign markets is appears somewhat ambiguous. The level effects of concentration of ownership appear to be negative as the correlation between measures of ownership concentration and export status are predominantly negative. In contrast, the effect of ownership concentration on the probability of becoming an exporter is positive, implying that firms with a more compact ownership structure are likelier to become first-time exporters. The observed correlations may be a byproduct of firm growth or its evolution, with younger firms almost by default having a more concentrated ownership structure than older more mature firms. If that were the case, the correlation between ownership structure and exporting would be spurious and a consequence of the underlying changes in the evolution of the firm. While firms size, as measured by the number of employees proxies for firm age to a certain degree, I also included firm age into the regression. The results, presented in the appendix, do not show any appreciable changes in either the sign or magnitude of coefficients of interest. 12

The evidence suggest that ownership concentration positively effects the likelihood of becoming an exporter, even once firm age is explicitly controlled for, but the effect of ownership on export intensity have so far not been explored. I remedy that in the following section by estimating a variant of equation 1 with export share as a dependent variable.

\section{Robustness check}

Another key aspect of ownership, that has so far not been explored, is stability of ownership. The relevant literature contends that ownership stability on average tends to improve firm performance. This is based on the assumption that stable ownership is more conducive to making long-term decisions on the evolution of the firm. Stable owners are more likely to forego quicker payoffs for less certain, but ultimately more rewarding choices. One of these choices is also the choice of breaking into foreign markets.

\footnotetext{
12 Given that I do not have information on actual age of the firms, I use year of earliest ownership entry as a proxy variable. For the vast majority of firms this also amounts to the year of incorporation.
} 
Table 8: Probit estimates of (1) [Dependent variable: Export status dummy (1), (2), and Export start dummy (3)]

\begin{tabular}{|c|c|c|c|}
\hline VARIABLES & $\begin{array}{c}(1) \\
\text { Export } \\
\text { status }\end{array}$ & $\begin{array}{c}(2) \\
\text { Export } \\
\text { status }\end{array}$ & $\begin{array}{c}(3) \\
\text { Export start } \\
\text { status }\end{array}$ \\
\hline Export status $_{\mathrm{t}-1}$ & & $\begin{array}{l}2.166^{* * * *} \\
(0.008)\end{array}$ & \\
\hline Single owner $r_{t-1}$ & $\begin{array}{l}-0.000 \\
(0.000)\end{array}$ & $\begin{array}{l}-0.000 \\
(0.000)\end{array}$ & $\begin{array}{l}-0.000 \\
(0.000)\end{array}$ \\
\hline $\operatorname{Ln}(\mathrm{VA} / \mathrm{emp})_{\mathrm{t}-1}$ & $\begin{array}{c}0.264 * * * \\
(0.003)\end{array}$ & $\begin{array}{c}0.120 * * * \\
(0.004)\end{array}$ & $\begin{array}{c}0.105 * * * \\
(0.007)\end{array}$ \\
\hline $\operatorname{Ln}(\mathrm{emp})_{\mathrm{t}-1}$ & $\begin{array}{c}0.298 * * * \\
(0.003)\end{array}$ & $\begin{array}{c}0.145 * * * \\
(0.003)\end{array}$ & $\begin{array}{c}0.097 * * * \\
(0.005)\end{array}$ \\
\hline $\operatorname{Ln}(\mathrm{K} / \mathrm{emp})_{\mathrm{t}-1}$ & $\begin{array}{c}0.082 * * * \\
(0.003)\end{array}$ & $\begin{array}{c}0.054 * * * \\
(0.004)\end{array}$ & $\begin{array}{c}0.038 * * * \\
(0.005)\end{array}$ \\
\hline $\operatorname{Ln}(\text { no. of owners })_{t-1}$ & $\begin{array}{l}-0.013 \\
(0.009)\end{array}$ & $\begin{array}{l}-0.008 \\
(0.012)\end{array}$ & $\begin{array}{l}-0.034 * \\
(0.019)\end{array}$ \\
\hline Share of top 5 owners $_{\mathrm{t}-1}$ & $\begin{array}{c}0.330 * * * \\
(0.062)\end{array}$ & $\begin{array}{l}0.171 * * \\
(0.083)\end{array}$ & $\begin{array}{c}0.202 \\
(0.125)\end{array}$ \\
\hline HHI (ownership) $)_{t-1}$ & $\begin{array}{c}-0.172 * * * \\
(0.019)\end{array}$ & $\begin{array}{c}-0.112^{* * * *} \\
(0.026)\end{array}$ & $\begin{array}{c}-0.158 * * * \\
(0.040)\end{array}$ \\
\hline Foreign majority owner & $\begin{array}{c}0.618 * * * \\
(0.037)\end{array}$ & $\begin{array}{c}0.316^{* * *} \\
(0.048)\end{array}$ & $\begin{array}{l}0.183 * * \\
(0.084)\end{array}$ \\
\hline Private inst. ownership & $\begin{array}{c}-0.088 * * * \\
(0.021)\end{array}$ & $\begin{array}{l}-0.024 \\
(0.029)\end{array}$ & $\begin{array}{c}0.024 \\
(0.041)\end{array}$ \\
\hline Physical person owners & $\begin{array}{c}0.053 * * * \\
(0.012)\end{array}$ & $\begin{array}{c}0.092 * * * \\
(0.018)\end{array}$ & $\begin{array}{c}0.138 * * * \\
(0.025)\end{array}$ \\
\hline State direct ownership & $\begin{array}{c}0.169 \\
(0.246)\end{array}$ & $\begin{array}{c}0.409 \\
(0.315)\end{array}$ & $\begin{array}{c}3.657 \\
(103.496)\end{array}$ \\
\hline State indirect ownership & $\begin{array}{c}0.397 * * * \\
(0.139)\end{array}$ & $\begin{array}{c}0.318 \\
(0.205)\end{array}$ & $\begin{array}{c}0.698 \\
(0.431)\end{array}$ \\
\hline Age & $\begin{array}{c}-0.011 * * * \\
(0.000)\end{array}$ & $\begin{array}{c}-0.012 * * * \\
(0.001)\end{array}$ & $\begin{array}{c}-0.012 * * * \\
(0.001)\end{array}$ \\
\hline Institutional volatility & $\begin{array}{l}0.050^{*} \\
(0.029)\end{array}$ & $\begin{array}{l}-0.008 \\
(0.037)\end{array}$ & $\begin{array}{c}0.005 \\
(0.051)\end{array}$ \\
\hline Ownership persistence & $\begin{array}{l}0.000 * * \\
(0.000)\end{array}$ & $\begin{array}{c}0.000 \\
(0.000)\end{array}$ & $\begin{array}{l}0.000 \\
(0.000)\end{array}$ \\
\hline Constant & $\begin{array}{c}-4.836 * * * \\
(0.254)\end{array}$ & $\begin{array}{c}-3.511 * * * \\
(0.327)\end{array}$ & $\begin{array}{c}-6.612 \\
(103.496)\end{array}$ \\
\hline Time dummies & YES & YES & YES \\
\hline Industry dummies & YES & YES & YES \\
\hline Legal status dummies & $\frac{\text { YES }}{241.557}$ & $\frac{\text { YES }}{203625}$ & YES \\
\hline $\begin{array}{l}\text { Observations } \\
\text { Pseudo R }{ }^{2}\end{array}$ & $\begin{array}{c}241,557 \\
0.223\end{array}$ & $\begin{array}{c}203,625 \\
0.523\end{array}$ & $\begin{array}{c}118,487 \\
0.048\end{array}$ \\
\hline
\end{tabular}

Table 8 displays the estimates of 1 controlling for ownership stability using "institutional volatility" and "ownership persistence" variables with randomeffects probit. Concentration of ownership at the five largest owners is again 
revealed to have a positive effect on both the probability of being an exporter as well as the probability of becoming a first-time exporter. Interestingly though, once ownership stability is explicitly controlled for, foreign ownership no longer exerts a statistically significant impact on the probability of being an exporter or the probability of becoming a first-time exporter.

Similarly, domestic individual ownership no longer has a significant positive correlation with exporting. The primary reason for the loss of significance is the reduced sample size and the fact that the sample is based solely on public-stock companies. The strong positive effect of both foreign and individual domestic owners in previous regressions is driven exclusively by limited liability companies, which represent the majority of the population of firms. Most of the studies exploring the effects of foreign-ownership tend to ignore the formal impact an acquisition has on the ownership structure in terms of both the concentration of ownership and the added effect on the stability of ownership. Results here indicate that empirical work on the impact of foreign ownership should, at the very least, account for the accompanying changes to the structure of ownership and possibly also on the changes to ownership stability. Only after accounting for the changes to the ownership structure can the true impact of foreign ownership be properly analyzed.

One final robustness check is performed by allowing the coefficients on the ownership variables to vary according to firm type. Table A2 of the appendix confirms the findings hold for both firm types. Both for limited-liability and jointstock companies ownership concentration leads to a greater likelihood of being exporters.

\section{Effect of ownership structure on export intensity}

I explore the effect ownership structure has on firm export intensity by estimating regression (1) on the share of export revenue in total sales volume. Column 1 shows estimates with OLS, while Pseudo-Poisson maximum likelihood estimates are presented in column 2 . The reason for the latter is a very high share of non-exporters in the sample, which results in a skewed distribution of the dependent variable. Finally, in column 3 effects of ownership structure on changes in the export share with the OLS estimator. 
Estimation results presented in Table 7 show that foreign ownership stimulates higher export intensities, while ownership of domestic institutional owners has a negative effect.

Effects of ownership on export share are nuanced. Given the significantly positive estimate of the number of owners on export share, it appears that firms with more dispersed ownership have a higher share of exports in total sales. Although positive in the PPML estimation (column 2) the share of largest and five largest owners do not have a significant effect on export share. The sign of the number-of-owners coefficient switches to negative in the export-share growth equation.

Table 7: Pseudo-Poisson maximum likelihood and OLS estimates of (2)

\begin{tabular}{|c|c|c|c|}
\hline VARIABLES & $\begin{array}{l}\text { (1) } \\
\text { Export share } \\
\text { OLS }\end{array}$ & $\begin{array}{l}\text { (2) } \\
\text { Export share } \\
\text { PPML }\end{array}$ & $\begin{array}{l}\text { (3) } \\
\text { Growth of } \\
\text { export share } \\
\text { OLS }\end{array}$ \\
\hline Export share $_{t-1}$ & & & $\begin{array}{c}-0.453 * * * \\
(0.012)\end{array}$ \\
\hline $\mathrm{Ln}(\mathrm{VA} / \mathrm{emp})_{\mathrm{t}-1}$ & $\begin{array}{c}0.021 * * * \\
(0.001)\end{array}$ & $\begin{array}{c}0.246 * * * \\
(0.012)\end{array}$ & $\begin{array}{c}0.021 * * * \\
(0.005)\end{array}$ \\
\hline $\operatorname{Ln}(\mathrm{emp})_{\mathrm{t}-1}$ & $\begin{array}{c}0.019 * * * \\
(0.001)\end{array}$ & $\begin{array}{c}0.166^{* * *} \\
(0.007)\end{array}$ & $\begin{array}{c}0.002 \\
(0.003)\end{array}$ \\
\hline $\operatorname{Ln}(\mathrm{K} / \mathrm{emp})_{\mathrm{t}-1}$ & $\begin{array}{c}0.001 \\
(0.001)\end{array}$ & $\begin{array}{l}-0.007 \\
(0.011)\end{array}$ & $\begin{array}{c}-0.022 * * * \\
(0.005)\end{array}$ \\
\hline $\operatorname{Ln}(\text { no. of owners })_{t-1}$ & $\begin{array}{l}0.005 * * \\
(0.003)\end{array}$ & $\begin{array}{l}0.026^{*} \\
(0.015)\end{array}$ & $\begin{array}{l}-0.011^{*} \\
(0.006)\end{array}$ \\
\hline Share of largest owner ${ }_{t-}$ & $\begin{array}{c}0.004 \\
(0.021)\end{array}$ & $\begin{array}{c}0.181 \\
(0.166)\end{array}$ & $\begin{array}{c}0.056 \\
(0.077)\end{array}$ \\
\hline Share of top 5 owners $_{\text {t- }}$ & $\begin{array}{l}-0.006 \\
(0.011)\end{array}$ & $\begin{array}{c}0.061 \\
(0.078)\end{array}$ & $\begin{array}{l}-0.046 \\
(0.034)\end{array}$ \\
\hline HHI (ownership) $)_{\mathrm{t}-1}$ & $\begin{array}{c}0.007 \\
(0.021)\end{array}$ & $\begin{array}{l}-0.126 \\
(0.161)\end{array}$ & $\begin{array}{l}-0.039 \\
(0.074)\end{array}$ \\
\hline Foreign majority owner & $\begin{array}{c}0.164 * * * \\
(0.011)\end{array}$ & $\begin{array}{c}0.585 * * * \\
(0.037)\end{array}$ & $\begin{array}{c}0.108 * * * \\
(0.030)\end{array}$ \\
\hline Private inst. ownership & $\begin{array}{c}-0.016 * * * \\
(0.005)\end{array}$ & $\begin{array}{c}-0.095 * * * \\
(0.033)\end{array}$ & $\begin{array}{c}0.014 \\
(0.026)\end{array}$ \\
\hline Physical person owners & $\begin{array}{c}0.003 \\
(0.002)\end{array}$ & $\begin{array}{l}0.034^{*} \\
(0.020)\end{array}$ & $\begin{array}{c}0.005 \\
(0.019)\end{array}$ \\
\hline State direct ownership & $\begin{array}{l}-0.002 \\
(0.035)\end{array}$ & $\begin{array}{l}-0.082 \\
(0.153)\end{array}$ & $\begin{array}{l}0.106^{*} \\
(0.058)\end{array}$ \\
\hline State indirect ownership & $\begin{array}{l}0.075^{*} \\
(0.044)\end{array}$ & $\begin{array}{c}0.155 \\
(0.144)\end{array}$ & $\begin{array}{c}0.144 * * * \\
(0.043)\end{array}$ \\
\hline Constant & $\begin{array}{c}-0.256^{* * *} \\
(0.023)\end{array}$ & $\begin{array}{c}-5.048 * * * \\
(0.212)\end{array}$ & $\begin{array}{l}0.160^{*} \\
(0.090)\end{array}$ \\
\hline Time dummies & YES & YES & YES \\
\hline Industry dummies & YES & YES & YES \\
\hline Legal status dummies & YES & YES & YES \\
\hline Observations & 220,567 & 220,489 & 65,937 \\
\hline
\end{tabular}




\begin{tabular}{lccc} 
R-squared & 0.139 & 0.165 & 0.160 \\
$\mathrm{~N}$ clust & 46,920 & 46,908 & 16,697 \\
\hline
\end{tabular}

Robust standard errors in parentheses

$* * * \mathrm{p}<0.01,{ }^{* *} \mathrm{p}<0.05,{ }^{*} \mathrm{p}<0.1$

Lastly, I run the regression model assuming that both the ownership variables as well as lagged labor productivity are endogenous. In considering ownership structure as endogeneous I follow the reasoning of Demsetz (1983), while heterogenous-firm trade literature has long since argued that exporting affects firm productivity dynamics as well as that more productive firms are more likely to start exporting. Ownership variables and labor productivity are instrumentalized using the system GMM estimator, which uses all available lagged levels and lagged differences as instruments for the endogenous variables.

\section{Accounting for endogeneity}

In order to account for endogeneity of ownership structure with respect to firm performance, equation 1 was re-estimated using system GMM. All available lags and differences of the number of owners, share of top 5 largest owners, $\mathrm{HHI}$ and labor productivity up to the third period lag were employed as instruments in the second estimation stage.

Table 9: System GMM estimates of (1) [Dependent variable: Export status dummy (1) and Export start dummy (2)]

\begin{tabular}{lcc}
\hline & $(1)$ & $(2)$ \\
VARIABLES & $\begin{array}{c}\text { Sys GMM on } \\
\text { export status }\end{array}$ & $\begin{array}{c}\text { Sys GMM on } \\
\text { export start }\end{array}$ \\
\hline Export status $_{\mathrm{t}-1}$ & $0.322^{* * *}$ & \\
& $(0.007)$ & \\
$\mathrm{Ln}(\mathrm{VA} / \mathrm{emp})_{\mathrm{t}-1}$ & $0.039^{* * *}$ & -0.004 \\
& $(0.003)$ & $(0.003)$ \\
$\mathrm{Ln}(\mathrm{emp})_{\mathrm{t}-1}$ & $0.060^{* * *}$ & $0.009^{* * *}$ \\
& $(0.001)$ & $(0.001)$ \\
$\mathrm{Ln}(\mathrm{K} / \mathrm{emp})_{\mathrm{t}-1}$ & $0.022^{* * *}$ & $0.012^{* * *}$ \\
& $(0.002)$ & $(0.002)$ \\
Ln(no. of owners $)_{\mathrm{t}-1}$ & 0.001 & $-0.032^{* *}$ \\
& $(0.010)$ & $(0.016)$ \\
Share of top 5 owners & $0.076^{* *}$ & -0.026 \\
& $(0.032)$ & $(0.044)$ \\
HHI (ownership) $)_{\mathrm{t}-1}$ & $-0.130^{* * *}$ & 0.032 \\
& $(0.031)$ & $(0.040)$
\end{tabular}




\begin{tabular}{lcc} 
Foreign majority owner & $0.034^{* * *}$ & 0.015 \\
& $(0.008)$ & $(0.023)$ \\
Private inst. ownership & 0.007 & 0.008 \\
& $(0.005)$ & $(0.007)$ \\
Physical person owners & $0.006^{*}$ & $0.009 * *$ \\
& $(0.003)$ & $(0.004)$ \\
State direct ownership & $-0.098^{* *}$ & 0.078 \\
& $(0.049)$ & $(0.077)$ \\
State indirect ownership & 0.026 & 0.028 \\
& $(0.038)$ & $(0.063)$ \\
Firm age & $-0.004^{* * *}$ & $-0.001^{* * *}$ \\
& $(0.000)$ & $(0.000)$ \\
Constant & $-0.125^{* * *}$ & $-0.177^{* * *}$ \\
& $(0.036)$ & $(0.059)$ \\
\hline Time dummies & YES & YES \\
Industry dummies & YES & YES \\
Legal status dummies & YES & YES \\
\hline Observations & 217,775 & 154,454 \\
Number of ids & 46,950 & 38,667 \\
Sargan $\chi^{2}(\mathrm{df})$ & $1126(482)$ & $1601(479)$ \\
\hline
\end{tabular}

Note: Up to three lags of $\ln (\text { VA/emp })_{t-1}$, $\ln (\text { no. of owners })_{t-1}$, Share of top 5 owners $t-1$, HHI (ownership) $)_{t-1}$ were used as instruments along with time-industry dummies. Robust standard errors in parentheses. $* * * \mathrm{p}<0.01,{ }^{* *} \mathrm{p}<0.05,{ }^{*} \mathrm{p}<0.1$

The estimates remain broadly consistent with the benchmark estimates as the positive effect of the share of the top five largest owners on the probability of a firm being an exporter is preserved. The effect of ownership concentration on the probability of becoming an exporter for the first time is no longer significant, but remains positive. Additionally, the impact of the number of owners on starting to export becomes significantly negative, reinforcing the belief that the concentration of ownership is more conducive to export participation. Furthermore, foreign and individual ownership remain important determinants of export status, but only the latter is statistically significant in the export-starter equation (2). Private institutional ownership continues to have a negative effect on the probability of being an exporter, which may be a consequence of subsidiary firms only providing inputs for future exports and not exporting directly to the foreign markets themselves. Even after controlling for firm age and ownership type, ownership concentration is associated with a higher probability of being an exporter or becoming one for the first time.

\section{Conclusion}


Despite a very long tradition of associating firm performance with the it's ownership structure in the corporate finance literature, the importance of ownership structure for export expansion and exporting has in general received scant attention. Considering that becoming involved with exporting is likely to be one of the most important decisions undertaken at a firm and that the effect of ownership on other firm decisions such as investment in research and development, expansion, etc. has been explored to great lengths, there is clearly a void in the literature on the effects of ownership structure on exporting. This paper fills the void by exploring the effects of ownership structure on exporting for the population of Slovene firms between 2005 and 2013.

I find that ownership concentration in fact stimulates the decision to become an exporter. Both current exporter status as well as the change from non-exporting to exporting status are associated with concentration of ownership. While there is some weak evidence on the positive correlation between the number of owners (share of top owner, ownership concentration index) on export activity, the relationship between the share of top five largest owners and measures of exposure to exports is robustly positive. This effect persists even when ownership stability and persistence are controlled for and is significant across both limited liability and joint-stock companies. Furthermore, I find a strong association between either foreign-ownership or individual domestic ownership with engagement in exporting. Domestic institutional owners and state ownership have a significantly negative effect on the probability of being or becoming an exporter. The former may be a consequence of the fact that institutional ownership may imply that these firms are suppliers to other domestic exporters and they themselves do not export. The negative effect of state ownership serves as another indication of the relative inefficiency of staterun firms and their primary orientation toward the domestic market.

Like many choices crucial to the firm, participation in exporting is associated with concentration of ownership. While there may be potential downsides to concentrated ownership, such firms appear to be better prepared to make swift and decisive decisions on the future of the firm. In terms of policy advice, the 
evidence strongly suggests that direct state ownership is not a desired feature for exporting firms.

\section{References}

1. Agrawal, A., Mandelker, G. N., 1990. Large shareholders and the monitoring of managers: the case of antitakeover charter amendments. Journal of Financial and Quantitative Analysis 25, 143-161.

2. Barclay, M., Holderness, C., 1989. Private benefits from control of public corporations. Journal of Financial Economics 25, 371-395

3. Berle, A., Means, G., 1932. The Modern Corporation and Private Property. Harcourt, Brace and World, New York

4. Blundell R., R. Griffith, and F. Windmeijer, 1999. Individual effects and dynamics in count data models. Journal of Econometrics, 108, 113-131.

5. Blundell R., R. Griffith, and J. Van Reenen, 2002. Market Share, Market Value and Innovation in a Panel of British Manufacturing Firms. The Review of Economic Studies, 66, 529-554.

6. Boycko, M., Shleifer, A., Vishny, R.W., 1996. A theory of privatization. The Economic Journal 106, 309-319.

7. Bushee, B. J., 1998. The influence of institutional investors on myopic R\&D investment behavior. Accounting Review 73, 305-333.

8. Calabro A., Torchia M., Pukall T., and Mussolino D., 2013. The influence of ownership structure and board strategic involvement on international sales: The moderating effect of family involvement. International Business Review 22(3), 509-523.

9. Chang, S.J., Hong, J., 2000. Economic performance of group-affiliated companies in Korea: Intragroup resource sharing and internal business transactions. Academy of Management Journal 43, 429-448.

10. Chang, S.J., Chung, C., Mahmood, I.P., 2006. When and how does business group affiliation promote firm innovation? A tale of two emerging economies. Organization Science 17, 637-656.

11. Chen, X., Harford, J., Li, K., 2007. Monitoring: Which institutions matter? Journal of Financial Economics, 86, 279-305

9. Claessens, S., Djankov, S., 1999. Ownership concentration and corporate performance in the Czech Republic. Journal of Comparative Economics 27, 498-513.

10. David, P., Hitt, M.A., Gimeno, J., 2001. The role of institutional investors in influencing R\&D. Academy of Management Journal 44, 144-157.

11. Demsetz, Harold, 1983. The structure of ownership and the theory of the firm. Journal of Law and Economics 26, 375-390

12. Demsetz, H., Lehn, K., 1985. The structure of corporate ownership: causes and consequences. Journal of Political Economy 93, 1155-1177

13. Demsetz, H. and B. Villalonga, 2001. Ownership structure and corporate performance 7, 209-233.

14. Dewenter, K.L., Malatesta, P.H., 2001. State-owned and privately-owned firms: an empirical analysis of profitability, leverage and labor intensity. American Economic Review 91, 320-334. 
15. Elyasiani, E., J. Jia, C. X. Mao, 2010. Institutional ownership stability and the cost of debt, Journal of Financial Markets, 13, 4, 475-500

16. Gaspar, J. M., Massa, M., Matos, P., 2005. Shareholder investment horizons and the market for corporate control. Journal of Financial Economics 76, 135-165

17. George G., J. Wiklund J., and Zahra S.A., 2005. Ownership and the internationalization of small firms Journal of Management, 31, pp. 210233

18. Himmelberg, C., Hubbard, G., Palia, D., 1999. Understanding the determinants of managerial ownership and the link between ownership and performance. Journal of Financial Economics 53, 353-384.

19. Hsu, M.F., \& Wang, K., 2014. The level and stability of institutional ownership and firm performance: Evidence from Taiwan. Emerging Markets Finance and Trade, 50, 159-173.

20. Kogut, B., 1983. Foreign direct investment as a sequential process. In: Kindleberger, C., Audretsch, D. (Eds.), The Multinational Corporation in the 1980s. The MIT Press, Cambridge, 35-56

21. Kruse, D.L., 1993. Profit Sharing: Does it Make a Difference? W.E. Upjohn Institute, Kalamazoo, MI.

22. Jensen, M., Meckling, W., 1976. Theory of the firm: Managerial behavior, agency costs and capital structure. Journal of Financial Economics 3, 305360

23. Johanson, J., Vahlne, J., 1977. The internationalization process of the firm: a model of knowledge development and increasing foreign market commitments. Journal of International Business Studies 8, 23-32.

24. Mahmood, I.P., Mitchell, W., 2004. Twofaces: Effects of business groups market share on innovation in emerging economies. Management Science $50,1348-1365$.

25. Mañez J.A., M.E. Rochina-Barrachina, J.A. Sanchis-Llopis, and O. Vicente 2014. Financial constraints and R\&D and exporting strategies for Spanish manufacturing firms. Industrial and corporate change. 23, 1563-1594.

26. McConnell, J., Servaes, H., 1990. Additional evidence on equity ownership and corporate value. Journal of Financial Economics 27, 595-612.

27. Miller D., Le Breton-Miller I., and Scholnick B., 2008. Stewardship vs. stagnation: An empirical comparison of small family and non-family businesses. Journal of Management Studies, 45, pp. 51-78.

28. Morck, R., Shleifer, A., Vishny, R.W., 1988. Management ownership and market valuation: an empirical analysis. Journal of Financial Economics 20, 293-315

29. Nickel, J., 1990. Can your organization achieve better results by sharing gains with employees? Employment Relations Today Autumn, 173-184.

30. Opler, T., Sokobin, J., 1997. Does coordinated institutional shareholder activism work? An analysis of the activities of the council of institutional investors, Working Paper, Ohio State University.

31. Prowse, S. D., 1992. The structure of corporate ownership in Japan. Journal of Finance 47, 1121-1140

32. Rowley, C., Bae, J., 2004. Big business in South Korea. Asia Pacific Business Review 10, 302-323. 
33. Shleifer, A., Vishny, R.W., 1986. Large shareholders and corporate control. Journal of Political Economy 94, 461-488

34. Shleifer, A., Vishny, R.W., 1996. A survey of corporate governance. Journal of Finance 52, 737-783

35. Stulz, R.M., 1988, On takeover resistance, managerial discretion, and shareholder wealth, Journal of Financial Economics, 20, 25-54.

36. Tesar, G., \& Moini, A. H. (1998). Longitudinal study of exporters and nonexporters: a focus on smaller manufacturing enterprises. International Business Review, 7 (3), 291-313.

37. Tihanyi, L., Johnson, R.A., Hoskisson, R.E., Hitt, M.A., 2003. Institutional ownership differences and international diversification: the effects of boards of directors and technological opportunity. Academy of Management Journal 46, 195-211

38. Zahra S. A., 1996. Governance, ownership, and corporate entrepreneurship: The moderating impact of industry technological opportunities. The Academy of Management Journal, 39, 1713-1735.

39. Zahra S. A., Pearce J. A., 1989. Boards of directors and corporate financial performance: A review and integrative model. Journal of Management, 15, 291-334. 


\section{Appendix}

Table A1: OLS estimates of (1) controlling for firm age [Dependent variable: Export status dummy (1) and Export start dummy (2)]

(1)

(2)

(3)

(4)

\begin{tabular}{|c|c|c|c|c|}
\hline VARIABLES & $\mathrm{P}\left(\operatorname{Exp}_{\mathrm{t}}=1\right)$ & $\mathrm{P}\left(\operatorname{Exp}_{\mathrm{t}}=1\right)$ & $\mathrm{P}\left(\operatorname{Exp}_{\mathrm{t}}=1\right)$ & $\mathrm{P}\left(\operatorname{Exp}_{\mathrm{t}}=1\right)$ \\
\hline $\mathrm{Ln}(\mathrm{VA} / \mathrm{emp})_{\mathrm{t}-1}$ & $\begin{array}{c}0.313 * * * \\
(0.004)\end{array}$ & $\begin{array}{c}0.312 * * * \\
(0.004)\end{array}$ & $\begin{array}{c}0.312 * * * \\
(0.004)\end{array}$ & $\begin{array}{c}0.312 * * * \\
(0.004)\end{array}$ \\
\hline $\operatorname{Ln}(e m p)_{t-1}$ & $\begin{array}{c}0.318 * * * \\
(0.003)\end{array}$ & $\begin{array}{l}0.319 * * * \\
(0.003)\end{array}$ & $\begin{array}{c}0.323 * * * \\
(0.003)\end{array}$ & $\begin{array}{c}0.318 * * * \\
(0.003)\end{array}$ \\
\hline $\operatorname{Ln}(\mathrm{K} / \mathrm{emp})_{\mathrm{t}-1}$ & $\begin{array}{c}0.059 * * * \\
(0.003)\end{array}$ & $\begin{array}{c}0.060 * * * \\
(0.003)\end{array}$ & $\begin{array}{c}0.061 * * * \\
(0.003)\end{array}$ & $\begin{array}{c}0.059 * * * \\
(0.003)\end{array}$ \\
\hline $\operatorname{Ln}(\text { no. of owners })_{t-1}$ & $\begin{array}{c}0.054 * * * \\
(0.006)\end{array}$ & & & \\
\hline $\begin{array}{c}\text { Share of largest } \\
\text { owner } \\
\text { t-1 }\end{array}$ & & $\begin{array}{c}-0.137 * * * \\
(0.012)\end{array}$ & & \\
\hline $\begin{array}{c}\text { Share of top } 5 \\
\text { owners } \\
\text { t }_{-1}\end{array}$ & & & $\begin{array}{c}0.022 \\
(0.033)\end{array}$ & \\
\hline HHI (ownership) $)_{t-1}$ & & & & $\begin{array}{c}-0.132 * * * \\
(0.011)\end{array}$ \\
\hline $\begin{array}{l}\text { Foreign majority } \\
\text { owner }\end{array}$ & $\begin{array}{c}0.570^{* * *} \\
(0.039)\end{array}$ & $\begin{array}{c}0.573 * * * \\
(0.039)\end{array}$ & $\begin{array}{c}0.558 * * * \\
(0.039)\end{array}$ & $\begin{array}{c}0.574 * * * \\
(0.039)\end{array}$ \\
\hline $\begin{array}{c}\text { Private institutional } \\
\text { ownership }\end{array}$ & $\begin{array}{c}-0.073 * * \\
(0.031)\end{array}$ & $\begin{array}{c}-0.075 * * \\
(0.032)\end{array}$ & $\begin{array}{c}-0.071 * * \\
(0.031)\end{array}$ & $\begin{array}{c}-0.072 * * \\
(0.032)\end{array}$ \\
\hline $\begin{array}{l}\text { Physical person } \\
\text { owners only }\end{array}$ & $\begin{array}{c}0.066^{* * * *} \\
(0.014)\end{array}$ & $\begin{array}{c}0.066 * * * \\
(0.014)\end{array}$ & $\begin{array}{c}0.066^{* * * *} \\
(0.014)\end{array}$ & $\begin{array}{c}0.065^{* * *} \\
(0.014)\end{array}$ \\
\hline State direct ownership & $\begin{array}{l}-0.208 \\
(0.160)\end{array}$ & $\begin{array}{l}-0.006 \\
(0.151)\end{array}$ & $\begin{array}{l}-0.109 \\
(0.149)\end{array}$ & $\begin{array}{l}-0.118 \\
(0.149)\end{array}$ \\
\hline $\begin{array}{l}\text { State indirect } \\
\text { ownership }\end{array}$ & $\begin{array}{c}0.418^{* *} \\
(0.166)\end{array}$ & $\begin{array}{c}0.384 * * \\
(0.166)\end{array}$ & $\begin{array}{c}0.491 * * * \\
(0.164)\end{array}$ & $\begin{array}{c}0.474 * * * \\
(0.165)\end{array}$ \\
\hline Age & $\begin{array}{c}-0.009 * * * \\
(0.001)\end{array}$ & $\begin{array}{c}-0.009 * * * \\
(0.001)\end{array}$ & $\begin{array}{c}-0.009 * * * \\
(0.001)\end{array}$ & $\begin{array}{c}-0.009 * * * \\
(0.001)\end{array}$ \\
\hline Constant & $\begin{array}{c}-4.629 * * * \\
(0.159)\end{array}$ & $\begin{array}{c}-4.410 * * * \\
(0.150)\end{array}$ & $\begin{array}{c}-4.542 * * * \\
(0.150)\end{array}$ & $\begin{array}{c}-4.398 * * * \\
(0.148)\end{array}$ \\
\hline Time dummies & YES & YES & YES & YES \\
\hline Legal status dummies & YES & YES & YES & YES \\
\hline Industry dummies & YES & YES & YES & YES \\
\hline Observations & 218,042 & 218,037 & 218,079 & 218,079 \\
\hline Pseudo $\mathrm{R}^{2}$ & 0.242 & 0.242 & 0.242 & 0.242 \\
\hline
\end{tabular}

Note: Robust standard errors in parentheses. ${ }^{* * *} \mathrm{p}<0.01,{ }^{* *} \mathrm{p}<0.05,{ }^{*} \mathrm{p}<0.1$

Table A2: OLS estimates of (1) breaking down the effect of domestic institutions

[Dependent variable: Export status dummy (1) and Export start dummy (2)] 


\begin{tabular}{|c|c|c|}
\hline VARIABLES & $\begin{array}{c}(1) \\
\mathrm{P}\left(\operatorname{Exp}_{\mathrm{t}}=1\right)\end{array}$ & $\begin{array}{c}(2) \\
\mathrm{P}\left(\operatorname{Exp}_{\mathrm{t}}=1 \mid \operatorname{Exp}_{\mathrm{t}-1}=0\right)\end{array}$ \\
\hline $\mathrm{Ln}(\mathrm{VA} / \mathrm{emp})_{\mathrm{t}-1}$ & $\begin{array}{l}0.311 * * * \\
(0.004)\end{array}$ & $\begin{array}{c}0.107 * * * \\
(0.006)\end{array}$ \\
\hline $\operatorname{Ln}(\mathrm{emp})_{\mathrm{t}-1}$ & $\begin{array}{c}0.322 * * * \\
(0.003)\end{array}$ & $\begin{array}{c}0.104 * * * \\
(0.004)\end{array}$ \\
\hline $\operatorname{Ln}(\mathrm{K} / \mathrm{emp})_{\mathrm{t}-1}$ & $\begin{array}{c}0.063 * * * \\
(0.003)\end{array}$ & $\begin{array}{l}0.059 * * * \\
(0.005)\end{array}$ \\
\hline $\operatorname{Ln}(\text { no. of owners })_{t-1}$ & $\begin{array}{l}-0.007 \\
(0.010)\end{array}$ & $\begin{array}{c}-0.044 * * \\
(0.018)\end{array}$ \\
\hline Share of largest owner ${ }_{t-1}$ & $\begin{array}{c}0.196 * * * \\
(0.072)\end{array}$ & $\begin{array}{c}0.011 \\
(0.117)\end{array}$ \\
\hline Share of top 5 owners $_{\mathrm{t}-1}$ & $\begin{array}{c}0.195 * * * \\
(0.039)\end{array}$ & $\begin{array}{c}0.223 * * * \\
(0.067)\end{array}$ \\
\hline HHI (ownership) $)_{t-1}$ & $\begin{array}{c}-0.341 * * * \\
(0.075)\end{array}$ & $\begin{array}{l}-0.189 \\
(0.123)\end{array}$ \\
\hline Foreign majority owner & $\begin{array}{c}0.573 * * * \\
(0.039)\end{array}$ & $\begin{array}{l}0.291 * * * \\
(0.069)\end{array}$ \\
\hline Domestic institutional & $\begin{array}{c}-0.076^{* * * *} \\
(0.028)\end{array}$ & $\begin{array}{c}0.031 \\
(0.046)\end{array}$ \\
\hline $\begin{array}{l}\text { Private non-financial } \\
\text { owners }\end{array}$ & $\begin{array}{l}-0.131^{*} \\
(0.079)\end{array}$ & $\begin{array}{c}-0.358 * * \\
(0.167)\end{array}$ \\
\hline Private financial owners & $\begin{array}{l}1.169^{*} \\
(0.643)\end{array}$ & $\begin{array}{c}-3.733 \\
(242.297)\end{array}$ \\
\hline Services firm dummy & $\begin{array}{c}-2.181 * * * \\
(0.091)\end{array}$ & $\begin{array}{c}-1.107 * * * \\
(0.147)\end{array}$ \\
\hline Serv*private financial & $\begin{array}{l}-1.098 \\
(0.678)\end{array}$ & $\begin{array}{c}3.608 \\
(242.297)\end{array}$ \\
\hline Serv*private non-finan & $\begin{array}{c}0.058 \\
(0.085)\end{array}$ & $\begin{array}{l}0.331^{*} \\
(0.173)\end{array}$ \\
\hline Supplier industry & $\begin{array}{c}0.150 * * * \\
(0.038)\end{array}$ & $\begin{array}{c}0.180 * * * \\
(0.063)\end{array}$ \\
\hline Physical person owners & $\begin{array}{c}0.061 * * * \\
(0.014)\end{array}$ & $\begin{array}{c}0.137 * * * \\
(0.021)\end{array}$ \\
\hline State direct ownership & $\begin{array}{c}-0.812 * * * \\
(0.192)\end{array}$ & $\begin{array}{l}-0.416 \\
(0.388)\end{array}$ \\
\hline Firm age & $\begin{array}{c}-0.010 * * * \\
(0.001)\end{array}$ & $\begin{array}{c}-0.016 * * * \\
(0.001)\end{array}$ \\
\hline Constant & $\begin{array}{c}-4.517^{* * *} \\
(0.135)\end{array}$ & $\begin{array}{c}-3.042 * * * \\
(0.240)\end{array}$ \\
\hline Time dummies & YES & YES \\
\hline Industry dummies & YES & YES \\
\hline Legal status dummies & YES & YES \\
\hline Observations & 217,699 & 154,326 \\
\hline Adj. R2 & 0.242 & 0.056 \\
\hline
\end{tabular}

Note: Robust standard errors in parentheses. ${ }^{* * *} \mathrm{p}<0.01,{ }^{* *} \mathrm{p}<0.05,{ }^{*} \mathrm{p}<0.1$ 
Table A3: OLS estimates of (1) allowing for flexibility of ownership effects [Dependent variable: Export status dummy (1) and Export start dummy (2)]

\begin{tabular}{|c|c|c|c|}
\hline VARIABLES & $\mathrm{P}\left(\operatorname{Exp}_{\mathrm{t}}=1\right)$ & $\begin{array}{c}(2) \\
\mathrm{P}\left(\operatorname{Exp}_{\mathrm{t}}=1\right)\end{array}$ & $\begin{array}{c}(3) \\
\mathrm{P}\left(\operatorname{Exp}_{\mathrm{t}}=1 \mid \operatorname{Exp}_{\mathrm{t}-1}=0\right)\end{array}$ \\
\hline Export status $_{\mathrm{t}-1}$ & - & $\begin{array}{c}2.083 * * * \\
(0.008)\end{array}$ & - \\
\hline Single owner_LL & $\begin{array}{c}-0.072 * * * \\
(0.014)\end{array}$ & $\begin{array}{c}-0.056^{* * *} \\
(0.016)\end{array}$ & $\begin{array}{l}-0.025 \\
(0.021)\end{array}$ \\
\hline Single owner SC & $\begin{array}{c}-1.929 * * \\
(0.835)\end{array}$ & $\begin{array}{l}-0.763 \\
(1.060)\end{array}$ & - \\
\hline More owners SC & $\begin{array}{l}-0.371 \\
(0.423)\end{array}$ & $\begin{array}{l}-0.048 \\
(0.525)\end{array}$ & $\begin{array}{l}-0.742 \\
(0.946)\end{array}$ \\
\hline $\mathrm{Ln}(\mathrm{VA} / \mathrm{emp})_{\mathrm{t}-1}$ & $\begin{array}{l}0.311^{* * *} \\
(0.004)\end{array}$ & $\begin{array}{l}0.161^{* * *} \\
(0.005)\end{array}$ & $\begin{array}{l}0.107 * * * \\
(0.006)\end{array}$ \\
\hline $\operatorname{Ln}(\mathrm{emp})_{\mathrm{t}-1}$ & $\begin{array}{l}0.320 * * * \\
(0.003)\end{array}$ & $\begin{array}{c}0.167 * * * \\
(0.003)\end{array}$ & $\begin{array}{l}0.102 * * * \\
(0.004)\end{array}$ \\
\hline $\operatorname{Ln}(\mathrm{K} / \mathrm{emp})_{\mathrm{t}-1}$ & $\begin{array}{c}0.060 * * * \\
(0.003)\end{array}$ & $\begin{array}{c}0.035 * * * \\
(0.004)\end{array}$ & $\begin{array}{c}0.058 * * * \\
(0.005)\end{array}$ \\
\hline $\operatorname{Ln}(\text { no. of owners })_{\mathrm{t}-1}$ & $\begin{array}{c}-0.101^{* * *} \\
(0.016)\end{array}$ & $\begin{array}{c}-0.056^{* * *} \\
(0.020)\end{array}$ & $\begin{array}{c}-0.115^{* * *} \\
(0.029)\end{array}$ \\
\hline Share of top 5 owners $_{\mathrm{t}-1}$ & $\begin{array}{c}0.243 * * * \\
(0.052)\end{array}$ & $\begin{array}{l}0.116^{*} \\
(0.063)\end{array}$ & $\begin{array}{c}0.240 * * * \\
(0.089)\end{array}$ \\
\hline HHI (ownership) $)_{\mathrm{t}-1}$ & $\begin{array}{l}-0.124^{*} \\
(0.069)\end{array}$ & $\begin{array}{c}0.026 \\
(0.084)\end{array}$ & $\begin{array}{l}-0.018 \\
(0.114)\end{array}$ \\
\hline $\operatorname{Ln}(\text { no. of owners })_{\mathrm{t}-1} * \mathrm{so}_{-} 11$ & $\begin{array}{c}0.100 * * * \\
(0.024)\end{array}$ & $\begin{array}{l}0.049 * \\
(0.030)\end{array}$ & $\begin{array}{l}0.084 * * \\
(0.042)\end{array}$ \\
\hline Share of top 5 owners $_{\mathrm{t}-1}{ }^{*} \mathrm{so}_{-} 11$ & $\begin{array}{l}-0.251 * * * \\
(0.051)\end{array}$ & $\begin{array}{l}-0.109 * \\
(0.063)\end{array}$ & $\begin{array}{l}-0.120 \\
(0.088)\end{array}$ \\
\hline HHI (ownership) $)_{\mathrm{t}-1}{ }^{*}$ so_ll & $\begin{array}{c}0.105 \\
(0.075)\end{array}$ & $\begin{array}{l}-0.033 \\
(0.092)\end{array}$ & $\begin{array}{l}-0.098 \\
(0.124)\end{array}$ \\
\hline Ln(no. of owners $)_{\mathrm{t}-1}{ }^{*}$ so_sc & $\begin{array}{l}1.003 * * * \\
(0.278)\end{array}$ & $\begin{array}{c}0.706^{* *} \\
(0.349)\end{array}$ & - \\
\hline Share of top 5 owners $_{\mathrm{t}-1}{ }^{*} \mathrm{so} \_\mathrm{sc}$ & $\begin{array}{c}-2.964 * * \\
(1.192)\end{array}$ & $\begin{array}{c}-3.340 * * \\
(1.432)\end{array}$ & - \\
\hline HHI (ownership) $)_{t-1}{ }^{*}$ so_sc & $\begin{array}{c}1.944 \\
(1.377)\end{array}$ & $\begin{array}{c}2.173 \\
(1.636)\end{array}$ & - \\
\hline Ln(no. of owners $)_{\mathrm{t}-1} *_{\text {mo_sc }}$ & $\begin{array}{c}0.091 * * * \\
(0.034)\end{array}$ & $\begin{array}{c}0.037 \\
(0.042)\end{array}$ & $\begin{array}{c}0.047 \\
(0.071)\end{array}$ \\
\hline Share of top 5 owners $_{\mathrm{t}-1} *$ mo_sc & $\begin{array}{c}0.632 \\
(0.470)\end{array}$ & $\begin{array}{c}0.214 \\
(0.579)\end{array}$ & $\begin{array}{c}0.435 \\
(1.025)\end{array}$ \\
\hline HHI (ownership) $)_{t-1} *$ mo_sc & $\begin{array}{c}-0.624 * * \\
(0.310)\end{array}$ & $\begin{array}{l}-0.428 \\
(0.381)\end{array}$ & $\begin{array}{c}0.507 \\
(0.622)\end{array}$ \\
\hline Foreign majority owner & $\begin{array}{c}0.559 * * * \\
(0.039)\end{array}$ & $\begin{array}{c}0.272 * * * \\
(0.046)\end{array}$ & $\begin{array}{c}0.274 * * * \\
(0.069)\end{array}$ \\
\hline Private inst. ownership & $\begin{array}{c}-0.123 * * * \\
(0.023)\end{array}$ & $\begin{array}{c}-0.057 * * \\
(0.028)\end{array}$ & $\begin{array}{l}-0.006 \\
(0.038)\end{array}$ \\
\hline Physical person owners & $\begin{array}{c}0.048 * * * \\
(0.014)\end{array}$ & $\begin{array}{c}0.065 * * * \\
(0.017)\end{array}$ & $\begin{array}{c}0.130 * * * \\
(0.022)\end{array}$ \\
\hline State direct ownership & $\begin{array}{c}-0.734 * * * \\
(0.165)\end{array}$ & $\begin{array}{c}-0.308 \\
(0.206)\end{array}$ & $\begin{array}{l}-0.181 \\
(0.371)\end{array}$ \\
\hline State indirect ownership & $\begin{array}{c}0.260 \\
(0.171)\end{array}$ & $\begin{array}{c}0.216 \\
(0.215)\end{array}$ & $\begin{array}{c}0.310 \\
(0.403)\end{array}$ \\
\hline Age & $\begin{array}{c}-0.010 * * * \\
(0.001)\end{array}$ & $\begin{array}{c}-0.010^{* * *} \\
(0.001)\end{array}$ & $\begin{array}{c}-0.016 * * * \\
(0.001)\end{array}$ \\
\hline Constant & $-4.244 * * *$ & $-3.179 * * *$ & $-2.872 * * *$ \\
\hline
\end{tabular}




\begin{tabular}{lccc} 
& $(0.068)$ & $(0.082)$ & $(0.107)$ \\
\hline Time dummies & YES & YES & YES \\
Industry dummies & YES & YES & YES \\
Legal status dummies & YES & YES & YES \\
\hline Observations & 218,037 & 218,037 & 154,372 \\
Adj. $\mathrm{R}^{2}$ & 0.243 & 0.517 & 0.056 \\
\hline
\end{tabular}

Note: Robust standard errors in parentheses. ${ }^{* * *} \mathrm{p}<0.01,{ }^{* *} \mathrm{p}<0.05,{ }^{*} \mathrm{p}<0.1$ 